\title{
Fabrication and Characterization of Highly Sensitive Acetone Chemical Sensor Based on ZnO Nanoballs
}

\author{
Qu Zhou ${ }^{1, *}$, ChangXiang Hong ${ }^{1}$, Yao Yao ${ }^{2}$, Ahmed Mohamed Ibrahim ${ }^{3}$, Lingna Xu ${ }^{1}$, \\ Rajesh Kumar ${ }^{4}$, Sumaia Mohamed Talballa ${ }^{5}$, S. H. Kim ${ }^{6,7}$ and Ahmad Umar 6,7,* \\ 1 College of Engineering and Technology, Southwest University, Chongqing 400715, China; \\ hcx111000@163.com (C.H.); lingnaxu@cqu.edu.cn (L.X.) \\ 2 College of Communication Engineering, Chengdu University of Information Technology, Chengdu 610225, \\ China; yaoyao386@yahoo.com \\ 3 Department of Pharmaceutical Chemistry, Faculty of Pharmacy, Najran University, Najran 11001, \\ Saudi Arabia; shakiroon4health@gmail.com \\ 4 Department of Chemistry, Jagdish Chandra DAV College, Dasuya 144205, Punjab, India; \\ rk.ash2k7@gmail.com \\ 5 Department of Pathology, Faculty of Medicine, Najran University, Najran 11001, Saudi Arabia; \\ omsuhieb@yahoo.com \\ 6 Department of Chemistry, College of Science and Arts, Najran University, P.O. Box 1988, Najran 11001, \\ Saudi Arabia; semikim77@gmail.com \\ 7 Promising Centre for Sensors and Electronic Devices (PCSED), Najran University, P.O. Box 1988, \\ Najran 11001, Saudi Arabia \\ * Correspondence: zhouqul@swu.edu.cn (Q.Z.); ahmadumar786@gmail.com or umahmad@nu.edu.sa (A.U.); \\ Tel.: +86-023-6825-1265 (Q.Z.)
}

Received: 2 June 2017; Accepted: 7 July 2017; Published: 14 July 2017

\begin{abstract}
Highly sensitive acetone chemical sensor was fabricated using $\mathrm{ZnO}$ nanoballs modified silver electrode. A low temperature, facile, template-free hydrothermal technique was adopted to synthesize the $\mathrm{ZnO}$ nanoballs with an average diameter of $80 \pm 10 \mathrm{~nm}$. The XRD and UV-Vis. studies confirmed the excellent crystallinity and optical properties of the synthesized $\mathrm{ZnO}$ nanoballs. The electrochemical sensing performance of the $\mathrm{ZnO}$ nanoballs modified $\mathrm{AgE}$ towards the detection of acetone was executed by simple current-voltage $(I-V)$ characteristics. The sensitivity value of $\sim 472.33 \mu \mathrm{A} \cdot \mathrm{mM}^{-1} \cdot \mathrm{cm}^{-2}$ and linear dynamic range (LDR) of $0.5 \mathrm{mM}-3.0 \mathrm{mM}$ with a correlation coefficient $\left(R^{2}\right)$ of 0.97064 were obtained from the calibration graph. Experimental limit of detection (LOD) for $\mathrm{ZnO}$ nanoballs modified $\mathrm{AgE}$ was found to be $0.5 \mathrm{mM}$.
\end{abstract}

Keywords: $\mathrm{ZnO}$; nanoballs; acetone; current-voltage; electrochemical; sensor

\section{Introduction}

$\mathrm{ZnO}$ nanomaterials has received exceptional attention and interest worldwide among the research fraternity due to their unique properties such as large surface to volume ratio, non-toxicity, ease of synthesis, $n$-type semiconducting nature, wide band gap of $\sim 3.30 \mathrm{eV}$, large exciton binding energy, high thermal stability, excellent electrical, magnetic, catalytic properties, etc. [1-5]. A large variety of methods for synthesis of $\mathrm{ZnO}$ nanomaterials is reported in the literature which results in the formations of different morphologies like nano-mushrooms, fluffy nanoballs, nanorods, nanoribbons, nanowires, nanoflakes, nano/microspheres, nanocones, nanopillars, nano/micro flowers, nanoneedles, nanosheets, nanoaggregates, etc.

Among the various potential applications, real-time and reliable electrochemical sensing of harmful, toxic and explosive chemicals using $\mathrm{ZnO}$ nanostructured based electrochemical sensing, is widely studied. Such sensors offer advantages such as ambient stability, resistivity towards toxic and 
hazardous chemicals, chemical inertness, electrocatalytic activity and ease of fabrication. It has been reported that $n$-type semiconducting metal oxide nanomaterials enhance the rate of electron transfer between electrode and analyte molecules, which drastically improves the current response for target molecules [6]. Additionally, inorganic metal oxide nanoparticles serve as supra-molecular assembling units which provide large surface area for electrochemical sensing interface $[7,8]$. Electrical signals resulted from the interaction of the target analyte molecules and the $\mathrm{ZnO}$ nanostructured transducer layers, coated on the surface of the modified electrode, provide the valuable analytical information [9].

Toxic and highly hazardous chemicals such as nitrophenols [10,11], ammonia [12], CO [13], hydrazines [14,15], nitroanilines [16-18], hydrogen sulfide [19], ethanolamine [20], picric acid [21], ethyl acetate [22], ethanol [23], synthetic antioxidants and dyes in food articles [24,25], some bio-molecules like glucose [26-28], uric acid [29,30], urea [31,32], aspartic acid [33], dopamine [34], pH sensors [35], etc. have been detected and analyzed through electrochemical sensing techniques using $\mathrm{ZnO}$ modified electrochemical sensors. Recently, Ahmad et al. [18] reported a binder-free, stable, and highly efficient hydrazine chemical sensor based on vertically aligned $\mathrm{ZnO}$ nanorods directly grown on the surface of Ag electrode through a low-temperature solution process. The average diameter and length of $\mathrm{ZnO}$ nanorods were $\sim 50 \mathrm{~nm}$ and $2.2 \mu \mathrm{m}$ with a high aspect ratio of about 44 . Excellent sensitivity of $105.5 \mu \mathrm{A} \cdot \mu \mathrm{M}^{-1} \cdot \mathrm{cm}^{-2}$ with a linear dynamic range of $0.01-98.6 \mu \mathrm{M}$ and low detection limit of $0.005 \mu \mathrm{M}$. was observed. Unique lotus-leaf-like $\mathrm{ZnO}$ nanostructures deposited on FTO substrate showed very low-level detection of ethyl acetate with high sensitivity of $\sim 139.8 \mu \mathrm{A} \cdot \mathrm{mM}^{-1} \cdot \mathrm{cm}^{-2}$ and limit of detection of $\sim 0.26 \mathrm{mM}$ [22]. Ameen et al. [36] synthesized $\mathrm{ZnO}$ nanowhiskers through a hydrothermal method and utilized them as electron mediators for the fabrication of electrochemical sensors for detecting p-hydroquinone. As fabricated p-hydroquinone chemical sensor exhibited a substantially high sensitivity of $\sim 99.2 \mu \mathrm{A} \cdot \mu \mathrm{M}^{-1} \cdot \mathrm{cm}^{-2}$ with a very low detection limit of $\sim 4.5 \mu \mathrm{M}$ and linear dynamic range of $\sim 10-200 \mu \mathrm{M}$. Ibrahim et al. [21] observed a high sensitivity of $24.14 \mu \mathrm{A} \cdot \mathrm{mM}^{-1} \cdot \mathrm{cm}^{-2}$ with good LDR of $0.078-10.0 \mathrm{mM}$ against picric acid using electrochemical sensor based on $\mathrm{ZnO}$ nanostructures with cauliflower shaped morphologies. Tailoring the $\mathrm{ZnO}$ morphologies for acquiring large surface to volume ratio for better adsorption of the analyte species and hence fast charge transfer during the electrochemical process is one of the most critical and desired aspects of electrochemical sensing applications.

In the present work, a simple, low cost, and template-free hydrothermal method was adopted for the synthesis of $\mathrm{ZnO}$ nanoballs with highly rough surfaces. Morphological, structural, optical, crystal phases, vibrational and scattering properties of the $\mathrm{ZnO}$ nanoballs were evaluated through different analytic techniques. $\mathrm{ZnO}$ nanoballs were further utilized for the fabrication of highly sensitive acetone electrochemical sensors through $I-V$ techniques. The $\mathrm{ZnO}$ nanoballs modified $\mathrm{AgE}$ showed the high sensitivity towards acetone.

\section{Results and Discussion}

\subsection{Morphological, Structural, Optical and Compositions Properties of $\mathrm{ZnO}$ Nanoballs}

Figure 1 represents the field emission scanning electron microscopic (FESEM) images of the hydrothermally synthesized $\mathrm{ZnO}$ powders. Interestingly, almost ball shaped morphologies can be assigned to maximum of the $\mathrm{ZnO}$ particles from the low magnification (Figure 1a) as well as high magnification (Figure 1a,b) FESEM images. However, few $\mathrm{ZnO}$ structures with ellipsoidal and non-spherical shapes can also be seen. These $\mathrm{ZnO}$ nanoballs further form some agglomerated structures. The surface of the $\mathrm{ZnO}$ nanoballs is highly rough as confirmed from a close look at the high magnification FESEM image as shown in Figure 1c. The average diameter of the $\mathrm{ZnO}$ nanoballs is $80 \pm 10 \mathrm{~nm}$. The roughness of the $\mathrm{ZnO}$ nanoballs surface provides a high density of the active sites for the adsorption of the target analyte and $\mathrm{O}_{2}$ from the air. In Figure $1 \mathrm{~d}$ the energy dispersive spectroscopy (EDS) spectrum for the hydrothermally synthesized $\mathrm{ZnO}$ nanoballs is shown. The presence of peaks 
only for Zinc and oxygen atoms confirms the formation of the $\mathrm{ZnO}$ along with a high degree of purity for the synthesized $\mathrm{ZnO}$ nanoballs.

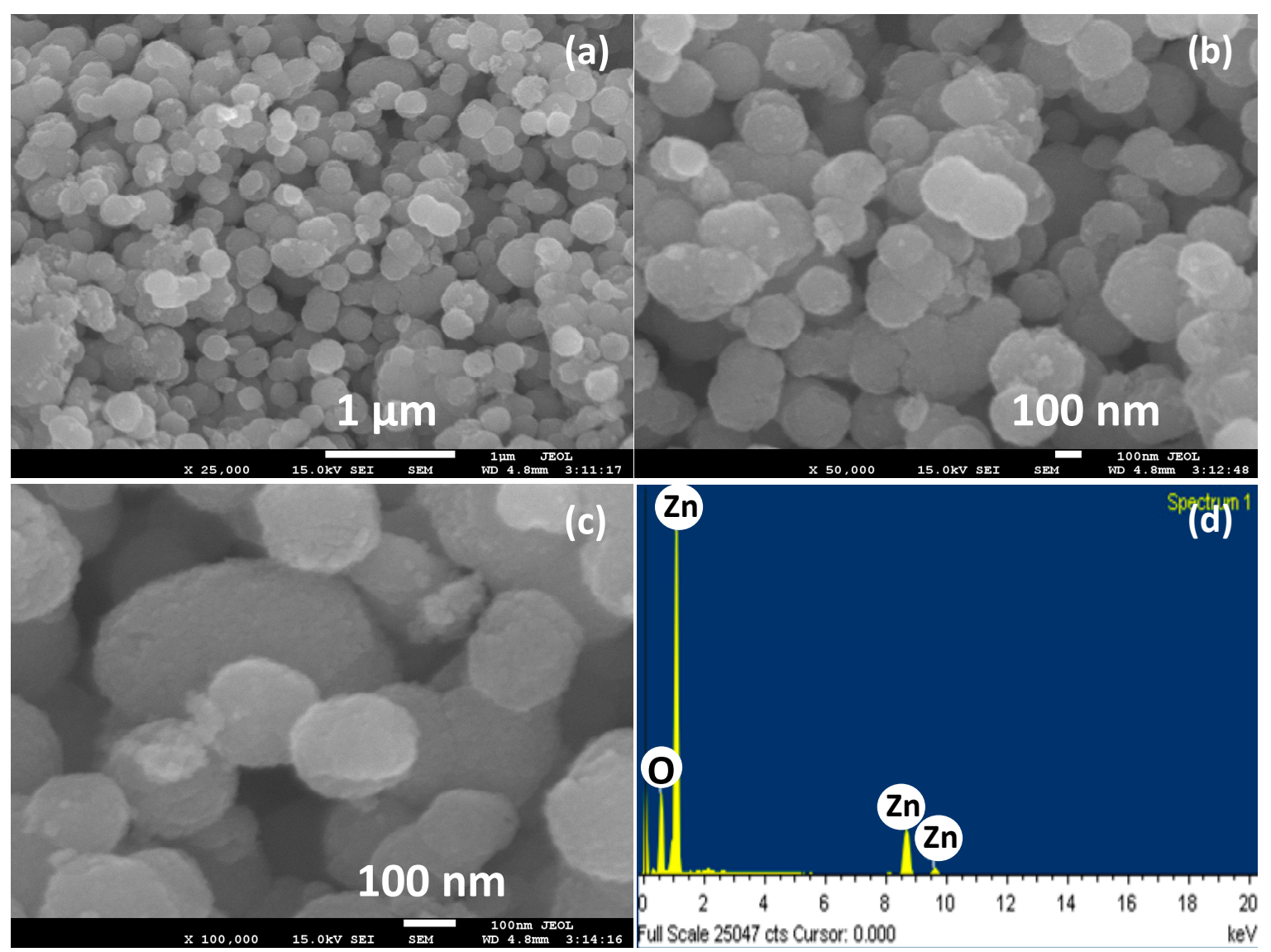

Figure 1. (a) Low magnification; and (b,c) high magnification FESEM images; and (d) EDS spectrum of ZnO nanoballs.

The crystallinity, crystalline size and microstructural phases for the $\mathrm{ZnO}$ nanoballs can be evaluated from the $\mathrm{X}$-ray diffraction (XRD) spectrum as shown in Figure 2. Well-defined diffractions peaks corresponding to the diffraction planes (100), (002), (101), (102), (110), (103), (200), (112), (201), (004) and (202) at diffraction angles $31.78^{\circ}, 34.43^{\circ}, 36.23^{\circ}, 47.63^{\circ}, 56.61^{\circ}, 62.91^{\circ}, 66.40^{\circ}, 67.95^{\circ}, 69.14^{\circ}$, $72.59^{\circ}$ and $76.71^{\circ}$, respectively, indicate the Wurtzite hexagonal phase for $\mathrm{ZnO}$ nanoballs. The results are supported by the JCPDS data card Nos. 36-1451 and reported literature [37-42]. No additional peak in the XRD spectrum related to any impurity, further confirms the results of EDS studies (Figure 1d).

Debye-Scherrer formula (Equation (1)) was used for calculating the crystallite size (d) of the $\mathrm{ZnO}$ nanoballs [43].

$$
\mathrm{d}=\frac{0.89 \lambda}{\beta \cdot \operatorname{Cos} \theta}
$$

where $\lambda=$ the wavelength of $X$-rays used $(1.54 \stackrel{\circ}{\mathrm{A}}), \theta$ is the Bragg diffraction angle and $\beta$ is the peak width at half maximum (FWHM). The FWHM values for the three most intense diffraction peaks corresponding to diffraction planes (100), (002) and (101) were taken into account. The corresponding results are given in Table 1. The average crystallite size of $\mathrm{ZnO}$ nanoballs was found to be $10.47 \mathrm{~nm}$. 
Table 1. The crystallite size of the hydrothermally synthesized $\mathrm{ZnO}$ nanoballs.

\begin{tabular}{ccccc}
\hline S.N & $\mathbf{( h k l )}$ & $\left.\mathbf{2 \theta} \mathbf{(}^{\circ}\right)$ & FWHM $(\boldsymbol{\beta})$ & Crystallite Size (nm) \\
\hline 1 & $(100)$ & 31.78 & 0.71936 & 11.36 \\
2 & $(002)$ & 38.43 & 0.80871 & 10.18 \\
3 & $(101)$ & 36.23 & 0.83756 & 9.88 \\
\hline
\end{tabular}

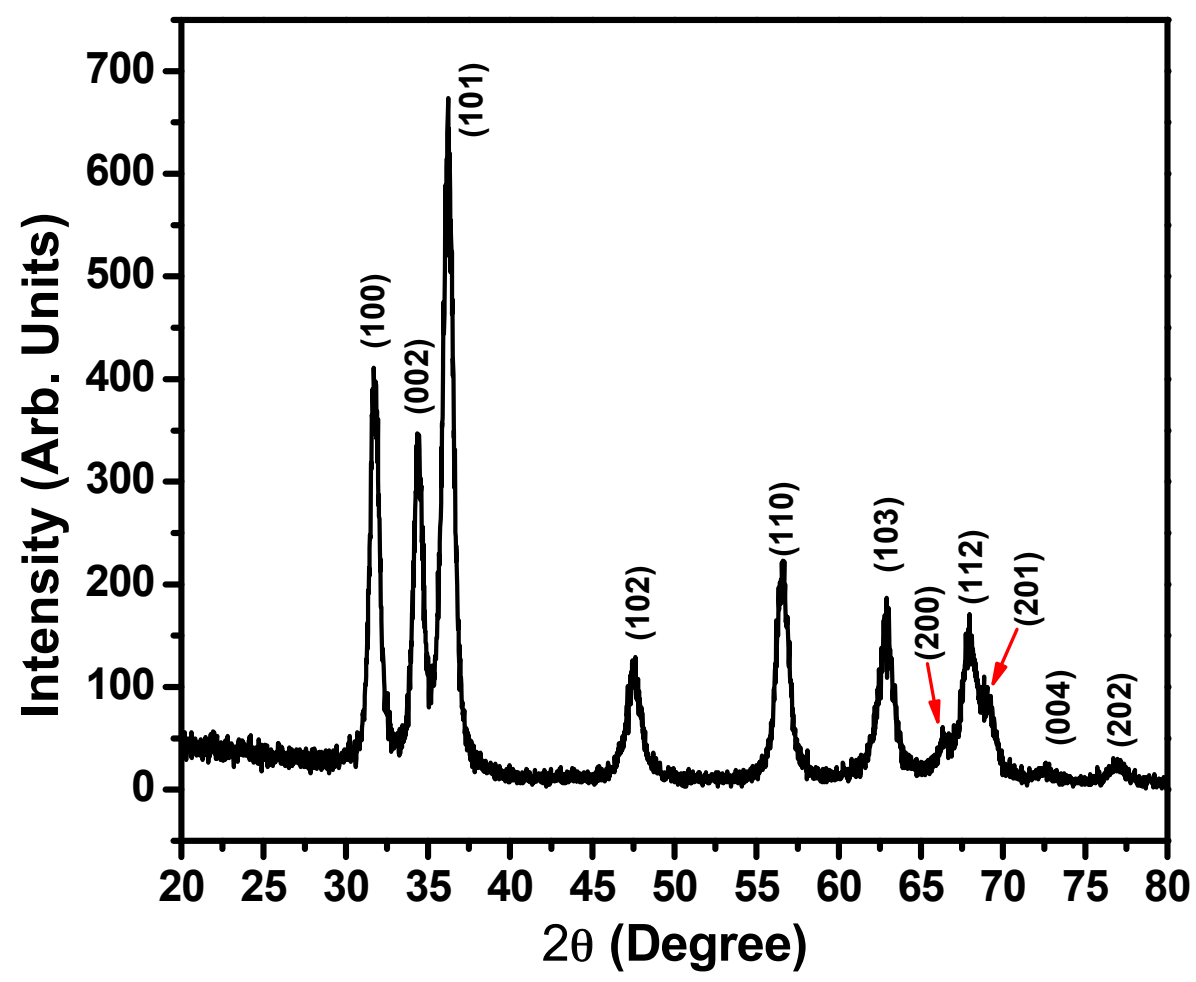

Figure 2. Typical XRD patterns for hydrothermally synthesized $\mathrm{ZnO}$ nanoballs.

Figure 3a represents the typical Fourier transform infrared (FTIR) spectrum of hydrothermally synthesized $\mathrm{ZnO}$ nanoballs. A sharp and well-defined peak at $476 \mathrm{~cm}^{-1}$ is the characteristic peak for metal-oxygen (M-O) bond and confirms the formation of the $\mathrm{Zn}-\mathrm{O}$ bond. Another broad band at $3446 \mathrm{~cm}^{-1}$ is due to the $\mathrm{O}-\mathrm{H}$ stretching vibrational modes of the water molecules physiosorbed on the surface of the $\mathrm{ZnO}$ nanoballs $[16,44-46]$.

In Figure $3 b$, the UV-Vis. spectrum plotted in the range of $200-550 \mathrm{~nm}$ is shown. A single and sharp absorption peak at $390 \mathrm{~nm}$ is observed. The band gap energy $\left(E_{g}\right)$ of $3.19 \mathrm{eV}$ was calculated with the help of well-known Planck's quantum equation (Equation (2)) [47].

$$
E_{g}=\frac{h c}{\lambda_{\max }}=\frac{6.625 \times 10^{-34} \mathrm{Js} \times 3 \times 10^{8} \mathrm{~ms}^{-1}}{390 \times 10^{-9} \mathrm{~m} \times 1.6 \times 10^{-19}}=3.19 \mathrm{eV}
$$

In order to evaluate the molecular vibrational, polarization and scattering information for the $\mathrm{ZnO}$ nanoballs, Raman-scattering analysis was performed at room temperature. Figure 4 represents the Raman scattering spectrum of the hydrothermally synthesized $\mathrm{ZnO}$ nanoballs.

Three distinct phonon peaks at 332, 382 and $438 \mathrm{~cm}^{-1}$ are the typical characteristic peaks of the $\mathrm{ZnO}$ wurtzite hexagonal phase and correspond to $\mathrm{E}_{2 \mathrm{H}}-\mathrm{E}_{2 \mathrm{~L}}$ multiphonon process, $\mathrm{A}_{1}(\mathrm{TO})$ and $\mathrm{E}_{2}^{\text {High }}$ modes, respectively [48]. Stronger $\mathrm{E}_{2}^{\mathrm{High}}$ indicates excellent crystal qualities and very low oxygen vacancies on the surface of the $\mathrm{ZnO}$ nanoballs [49]. 

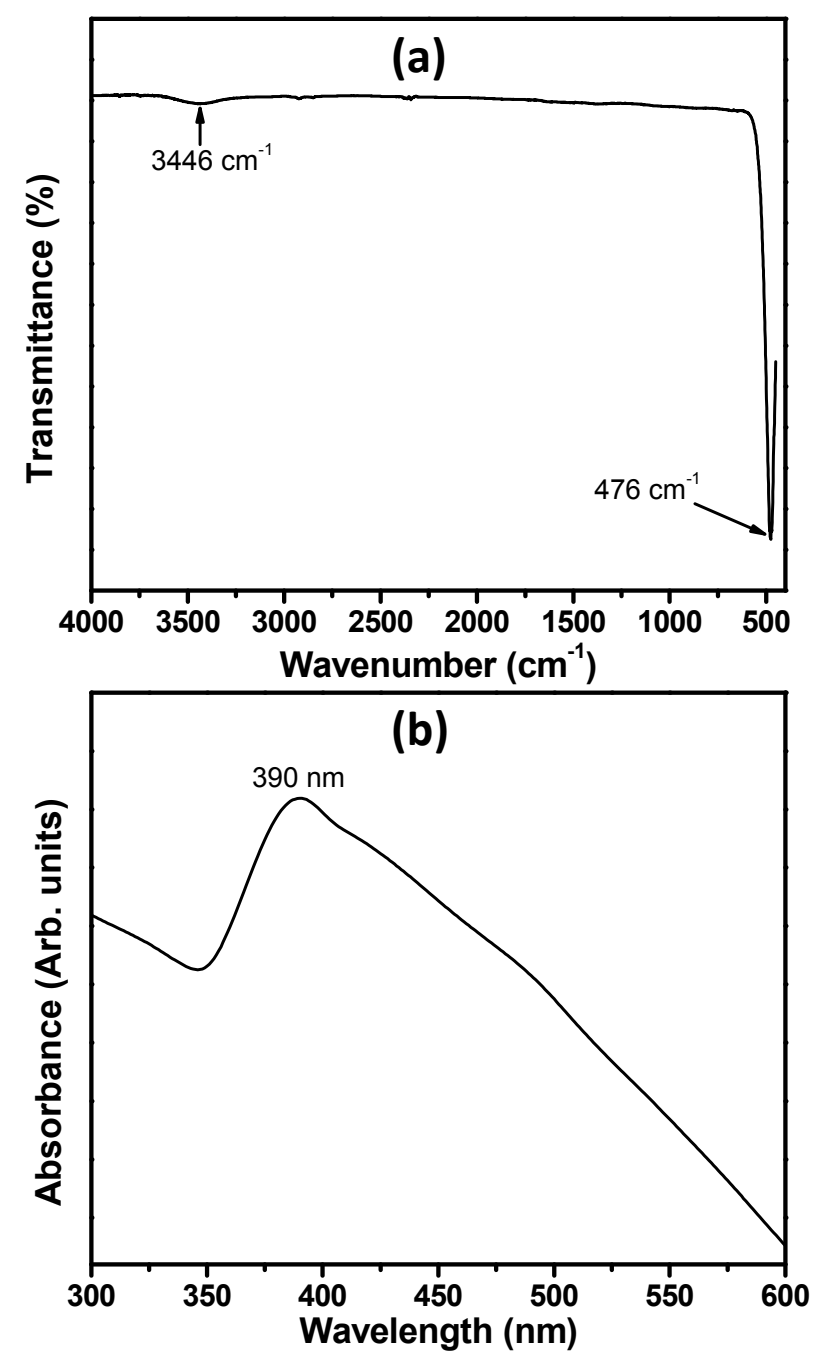

Figure 3. (a) FTIR; and (b) UV-Vis. spectra for hydrothermally synthesized ZnO nanoballs.

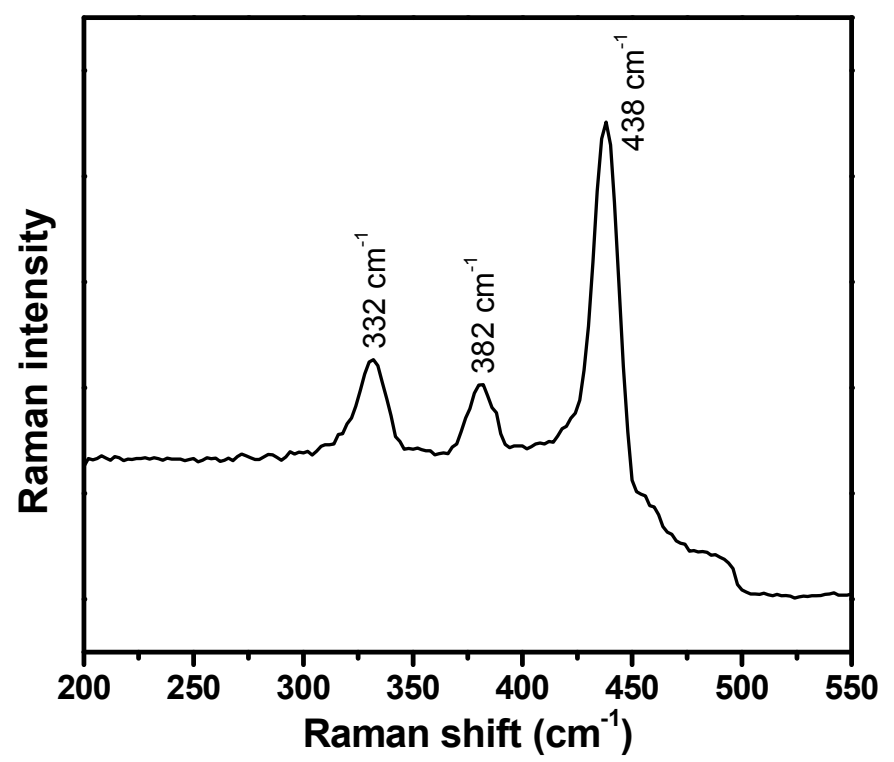

Figure 4. Raman spectrum for hydrothermally synthesized $\mathrm{ZnO}$ nanoballs. 


\subsection{Characterization of Acetone Sensor Fabricated Based on $\mathrm{ZnO}$ Nanoballs}

The potential electro-catalytic sensing applications of $\mathrm{ZnO}$ nanoballs coated onto the surface of the $\mathrm{AgE}$ are demonstrated in this section. Initial experimentations involves the comparison of $I-V$ responses of the $\mathrm{ZnO}$ nanoballs modified $\mathrm{AgE}$ for $0.5 \mathrm{mM}$ acetone solution prepared in the $0.1 \mathrm{M}$ PBS having $\mathrm{pH} 7.4$ and blank PBS within the potential range of $0.0-2.5 \mathrm{~V}$. As the applied potential increases, the current response increases remarkably for the PBS containing acetone as compared to blank PBS (Figure 5a). At an applied potential of $2.5 \mathrm{~V}$, the maximum current responses of 6.84221 and $1.6182 \mu \mathrm{A}$ were observed for $0.5 \mathrm{mM}$ acetone solutions and blank PBS, respectively. This substantial response of the $\mathrm{ZnO}$ nanoballs modified $\mathrm{AgE}$ towards the sensing of acetone confirms the involvement of the $\mathrm{ZnO}$ nanostructures in the efficient electrocatalytic activities and fast electron exchange capabilities. Figure $5 \mathrm{~b}$ represents the effect of the acetone concentration on the current responses of the $\mathrm{ZnO}$ nanoballs modified AgE. Different solutions of acetone with concentration range of $0.5 \mathrm{mM}-5.0 \mathrm{mM}$ were prepared in $0.1 \mathrm{M}$ PBS and were subjected to electrochemical analysis using $\mathrm{ZnO}$ nanoballs modified $\mathrm{AgE}$ as working electrode and a $\mathrm{Pt}$ wire as a counter electrode within the potential range of $0.0-2.5 \mathrm{~V}$. It can be seen that the increase in the concentration of the acetone resulted in a marked increase in the current responses.
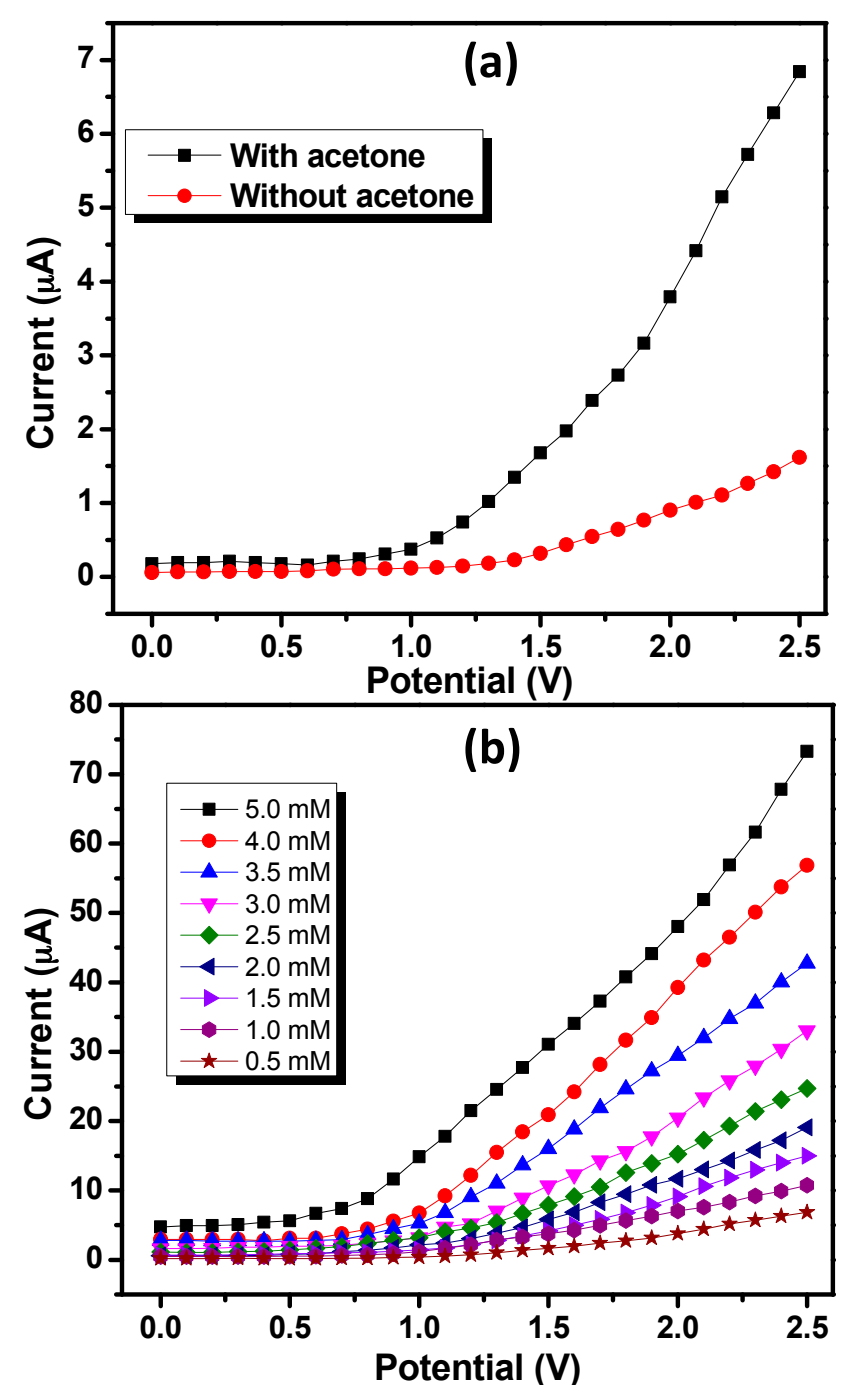

Figure 5. (a) $I-V$ responses measured for $0.5 \mathrm{mM}$ acetone in $0.1 \mathrm{M}$ PBS solution and blank PBS solution using $\mathrm{ZnO}$ nanoballs modified $\mathrm{AgE}$; and (b) $I-V$ response variations for $0.5 \mathrm{mM}-5.0 \mathrm{mM}$ concentrations of acetone in $0.1 \mathrm{M}$ PBS solution. 
At an applied potential of $2.5 \mathrm{~V}$, the current responses of $6.84221,10.7272,14.9831,19.0696,24.7101$, $33.013,42.7444,56.8836$ and $73.3094 \mu \mathrm{A}$ were recorded for $0.5,1.0,1.5,2.0,2.5,3.0,3.5,4.0$ and $5.0 \mathrm{mM}$ acetone solutions, respectively. Increased current responses with a concentration of the acetone can be attributed to the generation of a large number of ions and increased ionic strength of the analyte solutions [37].

Current vs. concentration calibration graph was plotted to determine the sensing parameters such as sensitivity, LOD and LDR (Figure 6). The sensitivity value of $\sim 472.33 \mu \mathrm{A} \cdot \mathrm{mM}^{-1} \cdot \mathrm{cm}^{-2}$ and LDR of $0.5 \mathrm{mM}-3.0 \mathrm{mM}$ with a correlation coefficient $\left(R^{2}\right)$ of 0.97064 were obtained from the calibration graph. Experimental LOD for $\mathrm{ZnO}$ nanoballs modified AgE was found to be $0.5 \mathrm{mM}$. As fabricated acetone sensors based on hydrothermally synthesized $\mathrm{ZnO}$ nanoballs exhibit better sensitivity compared to different sensors reported in the literature (Table 2).

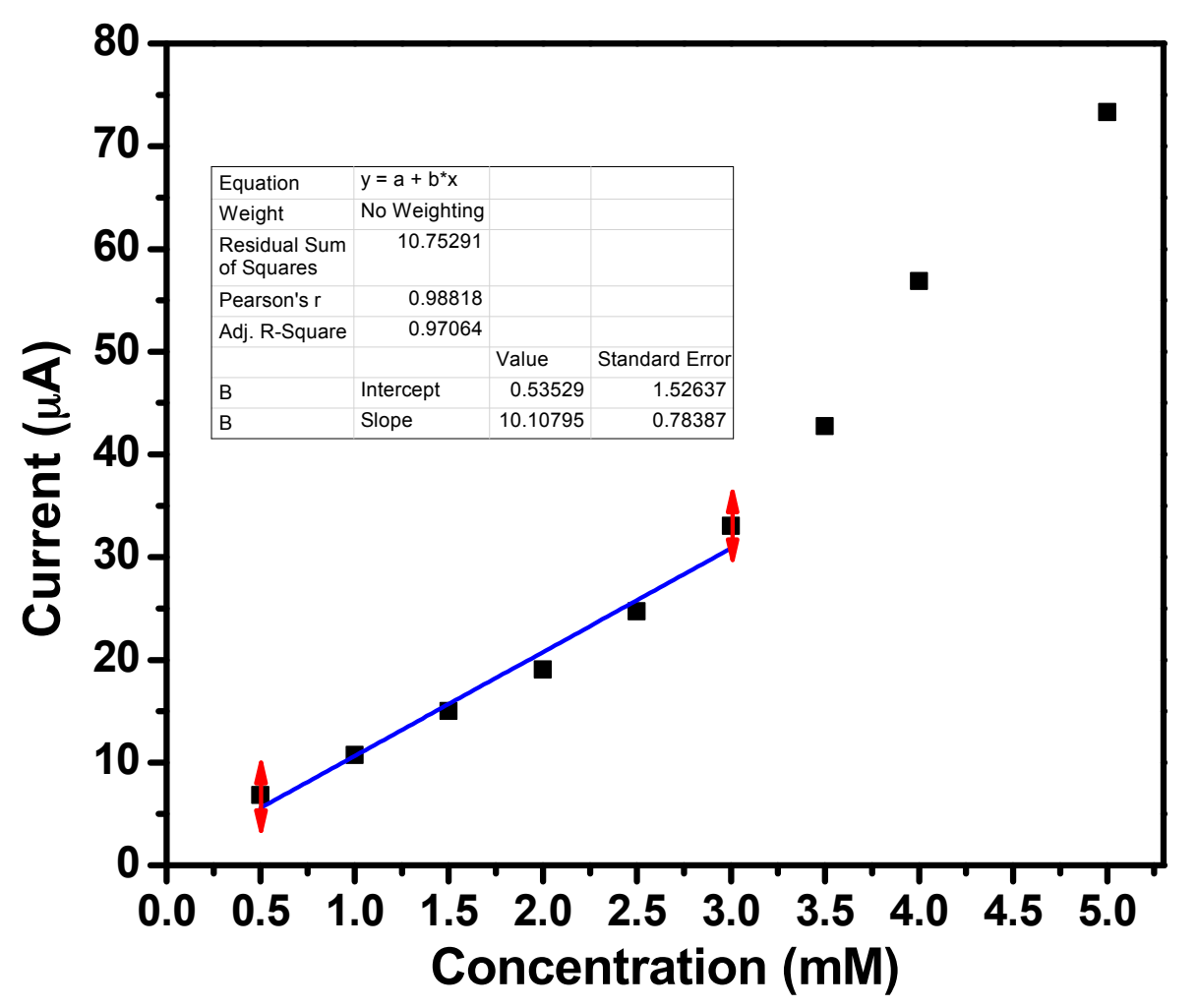

Figure 6. Calibration plot for $\mathrm{ZnO}$ nanoballs modified AgE towards acetone. 
Table 2. Summary of the acetone sensing performances of different sensor materials.

\begin{tabular}{|c|c|c|c|c|c|c|}
\hline Sensor & Method & Sensitivity & LDR & LOD & $\mathbf{R}^{2}$ & Ref. \\
\hline $\mathrm{ZnO}$-doped $\mathrm{Co}_{3} \mathrm{O}_{4}$ Nanorods/AgE & $I-V$ & $3.58 \mu \mathrm{A} \cdot \mathrm{mM}^{-1} \cdot \mathrm{cm}^{-2}$ & $66.8 \mu \mathrm{M}-0.133 \mathrm{mM}$ & $14.7 \pm 0.2 \mu \mathrm{M}$ & 0.9684 & [50] \\
\hline $\mathrm{ZnO} N P s / G C E$ & $I-V$ & $0.14065 \mu \mathrm{A} \cdot \mathrm{mM}^{-1} \cdot \mathrm{cm}^{-2}$ & $0.13 \mathrm{mM}-0.13 \mathrm{M}$ & $0.068 \pm 0.01 \mathrm{mM}$ & - & {$[51]$} \\
\hline Gd-ZnO-Nanopencils/AgE & $I-V$ & $208 \pm 62 \mu \mathrm{A} \cdot \mathrm{mM}^{-1} \cdot \mathrm{cm}^{-2}$ & $750 \mu \mathrm{M}-100 \mathrm{mM}$ & $0.7 \mathrm{mM}$ & 0.885 & {$[52]$} \\
\hline $\mathrm{ZnO} / \mathrm{SnO}_{2} / \mathrm{Yb}_{2} \mathrm{O}_{3} / \mathrm{GCE}$ & $I-V$ & $17.09 \mu \mathrm{A} \cdot \mathrm{mM}^{-1} \cdot \mathrm{cm}^{-2}$ & $0.34 \mathrm{nM}-3.4 \mathrm{mM}$ & $0.05 \pm 0.002 \mathrm{nM}$ & 0.9394 & [53] \\
\hline Lead foil electrode & Amperometric & $2.07 \mu \mathrm{A} \cdot \mathrm{cm}^{-2} \cdot \mathrm{ppm}^{-1}$ & $50-250 \mathrm{ppm}$ & $50 \mathrm{ppm}$ & 0.998 & [54] \\
\hline Electro-deposited $\mathrm{Pb}$ electrode & Amperometric & $4.16 \mu \mathrm{A} \cdot \mathrm{cm}^{-2} \cdot \mathrm{ppm}^{-1}$ & $100-400$ ppm & - & 0.99 & [55] \\
\hline $\mathrm{Ag}_{2} \mathrm{O}$ microflower/GCE & $I-V$ & $1.699 \mu \mathrm{A} \cdot \mathrm{mM}^{-1} \cdot \mathrm{cm}^{-2}$ & $0.13 \mu \mathrm{M}-0.67 \mathrm{M}$ & $0.11 \mu \mathrm{M}$ & 0.9462 & {$[56]$} \\
\hline $\mathrm{ZnO}$ nanoballs/AgE & $I-V$ & $472.33 \mu \mathrm{A} \cdot \mathrm{mM}^{-1} \cdot \mathrm{cm}^{-2}$ & $0.5 m M-3.0 m M$ & $0.5 \mathrm{mM}$ & 0.9706 & This work \\
\hline
\end{tabular}




\subsection{Proposed Sensing Mechanism}

It has been postulated in many studies that the adsorption of the molecular oxygen $\left(\mathrm{O}_{2}\right)$ from the PBS as well as from the surrounding environment onto the highly rough surface of the $\mathrm{ZnO}$ nanomaterials, is the key concern of the sensing applications. Surface reactions result in the formation of oxygenated anionic species such as superoxides $\left(\mathrm{O}_{2}^{-}\right)$, peroxides $\left(\mathrm{O}_{2}^{2-}\right)$, hydroxides $\left(\mathrm{HO}^{-}\right)$and oxides $\left(\mathrm{O}^{2-}\right)$ [57]. The reduction is aided through the conduction band electrons of the $\mathrm{ZnO}$ nanomaterials coated onto the surface of AgE (Equations (3)-(6)).

$$
\begin{gathered}
\mathrm{O}_{2(\mathrm{~g})} \rightarrow \mathrm{O}_{2} \text { (chemisorbed) } \\
\mathrm{O}_{2 \text { (chemisorbed) }}+\mathrm{e}^{-} \rightarrow \mathrm{O}_{2}^{-} \text {(Chemisorbed) } \\
\mathrm{O}_{2 \text { (chemisorbed) }}+2 \mathrm{e}^{-} \rightarrow \mathrm{O}_{2}^{2-} \text { (Chemisorbed) } \\
\mathrm{O}_{2 \text { (chemisorbed) }}+4 \mathrm{e}^{-} \rightarrow 2 \mathrm{O}_{(\text {Chemisorbed) }}^{2-}
\end{gathered}
$$

These chemisorbed oxygenated anionic species deplete the surface electron states of the $\mathrm{ZnO}$ and increase the resistance of the n-type semiconductor material due to the formation of an electron depletion layer at the $\mathrm{ZnO}$ nanoballs surfaces [58-61]. The increase in the current response is due to the release of the trapped electrons back into the conduction band during the catalytic oxidation the adsorbed acetone molecules into $\mathrm{CO}_{2}$ and $\mathrm{H}_{2} \mathrm{O}$ (Equations (7)-(10)) [18,44,62-64].

$$
\begin{aligned}
\mathrm{CH}_{3} \mathrm{COCH}_{3}+4 \mathrm{O}^{-} \text {(chemisorbed) } & \rightarrow \mathrm{CH}_{3} \mathrm{COOH}+\mathrm{CO}_{2}+\mathrm{H}_{2} \mathrm{O}+4 \mathrm{e}^{-} \\
\mathrm{CH}_{3} \mathrm{COOH}+4 \mathrm{O}^{-} \text {(chemisorbed) } & \rightarrow 2 \mathrm{CO}_{2}+2 \mathrm{H}_{2} \mathrm{O}+4 \mathrm{e}^{-} \\
\mathrm{CH}_{3} \mathrm{COCH}_{3}+4 \mathrm{O}_{2}^{-} \text {(chemisorbed) } & \rightarrow 3 \mathrm{CO}_{2}+3 \mathrm{H}_{2} \mathrm{O}+4 \mathrm{e}^{-} \\
\mathrm{CH}_{3} \mathrm{COCH}_{3}+8 \mathrm{O}^{2-} \text { (chemisorbed) } & \rightarrow 3 \mathrm{CO}_{2}+3 \mathrm{H}_{2} \mathrm{O}+16 \mathrm{e}^{-}
\end{aligned}
$$

On the basis of above discussion, the proposed sensing mechanism for $\mathrm{ZnO}$ nanoballs modified $\mathrm{AgE}$ against acetone is represented in Figure 7.

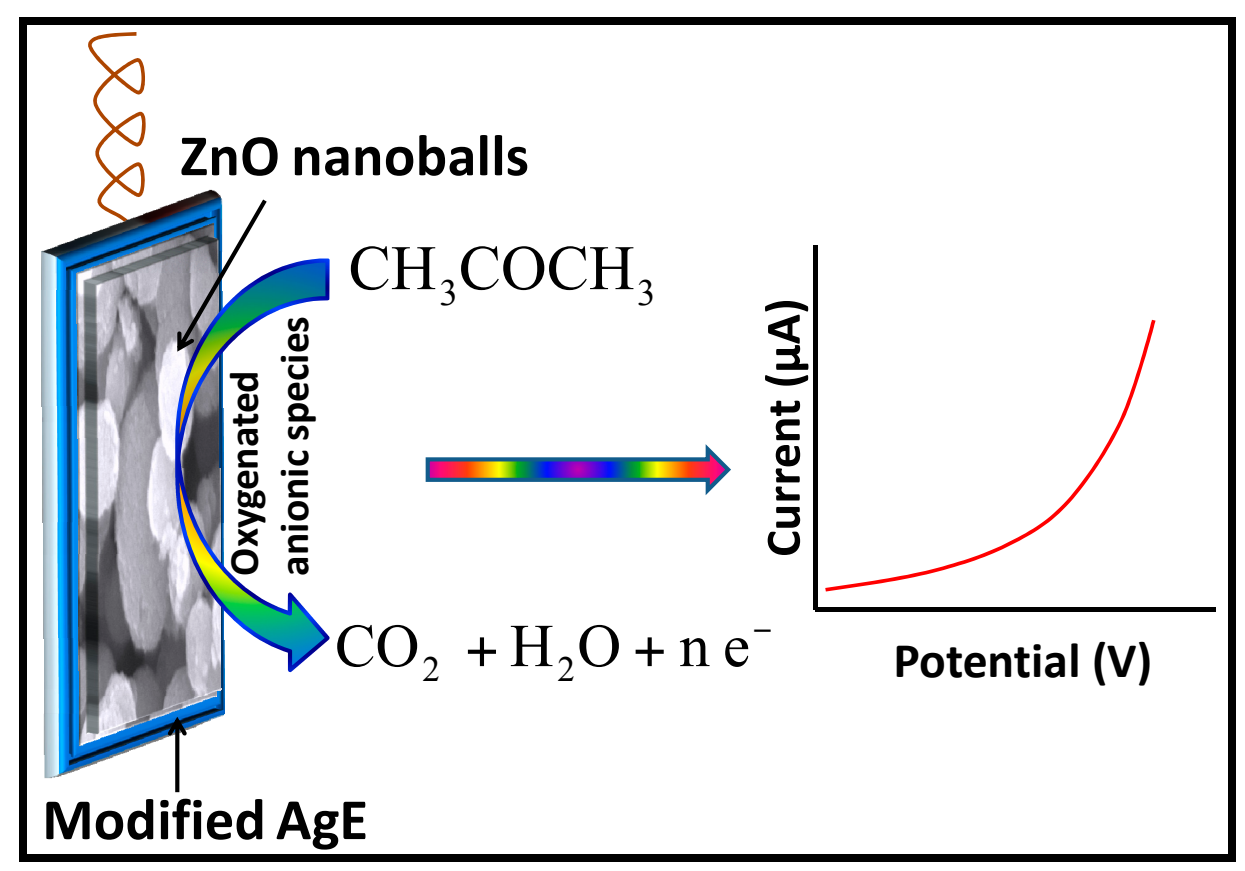

Figure 7. Proposed sensing mechanism for $\mathrm{ZnO}$ nanoballs modified AgE towards acetone in PBS. 
Thus, $\mathrm{ZnO}$ nanoballs pose excellent electron mediator activities for the detection and sensing of very low level of acetone in PBS at room temperature.

\section{Materials and Methods}

\subsection{Hydrothermal Synthesis of $\mathrm{ZnO}$ Nanoballs}

For the synthesis of the $\mathrm{ZnO}$ nanoballs, all chemicals were purchased from Sigma-Aldrich (St. Louis, MO, USA) and were used as received without any further refinement. All solutions were prepared in DI water. A facile hydrothermal method was adopted for the synthesis of $\mathrm{ZnO}$ nanoballs in which $50 \mathrm{~mL}$ of $0.02 \mathrm{M}$ Zinc nitrate hexahydrate $\left[\mathrm{Zn}\left(\mathrm{NO}_{3}\right)_{2} \cdot 6 \mathrm{H}_{2} \mathrm{O}\right]$ was continuously stirred for $30 \mathrm{~min}$ along with aqueous $\mathrm{NaOH}$ solution, added dropwise in order to maintain a $\mathrm{pH}$ of 10 . Thereafter the resulting solution was transferred to a Teflon-lined stainless steel autoclave which was heated to $150{ }^{\circ} \mathrm{C}$. After heating the autoclave for the desired growth time oh for $5 \mathrm{~h}$, it was slowly cooled to room temperature. The white product formed was filtered and washed with DI water and ethanol to remove any un-reacted reactants. Finally, the powder was dried at $70 \pm 2{ }^{\circ} \mathrm{C}$ for $2 \mathrm{~h}$ in a hot air oven and characterized for its morphological, optical, structural, compositional and electrochemical sensing applications using different analytical techniques.

\subsection{Fabrication of Acetone Sensor Based on $\mathrm{ZnO}$ Nanoballs}

The silver electrode of active surface area of $0.0214 \mathrm{~cm}^{2}$ was pre-cleaned using $0.05 \mu \mathrm{m}$ alumina slurry followed by thorough washings with distilled water and ethanol and finally dried for $1 \mathrm{~h}$ in hot air oven at $70^{\circ} \mathrm{C}$. A homogeneous thin paste of $\mathrm{ZnO}$ nanoballs was prepared in butyl carbital acetate (BCA) conducting solvent and was coated in the form of a thin layer over the surface of the Ag electrode. The coated Ag electrode was dried at $70{ }^{\circ} \mathrm{C}$ in an air oven for $4 \mathrm{~h}$. An electrochemical cell was then set up in which $\mathrm{ZnO}$ nanoballs modified $\mathrm{AgE}$ served as the working electrode and a Pt wire as the counter electrode. The current-voltage $(I-V)$ measurements for solutions of acetone with different concentrations were measured at room temperature in the presence of $0.1 \mathrm{M}$ phosphate buffer solution (PBS) with pH of 7.4 with the help of Keithley 6517A-USA electrometer (Tektronix, OR, USA) with computer interfacing. The acetone sensitivity was determined by generating a calibration curve of current vs. concentration. The sensitivity of the $\mathrm{ZnO}$ nanoballs modified $\mathrm{AgE}$ was determined from the ratio of the slope of the calibration graph plotted between current and concentration to the active surface area of modified AgE.

\subsection{Characterization of $\mathrm{ZnO}$ Nanoballs}

Field emission scanning electron microscopy (FESEM; JEOL-JSM-7600F, JEOL, Tokyo, Japan) integrated with EDS was examined in order to study the morphological, compositional, and structural properties of the hydrothermally synthesized ZnO nanoballs. X-ray diffraction (XRD; JDX-8030W,

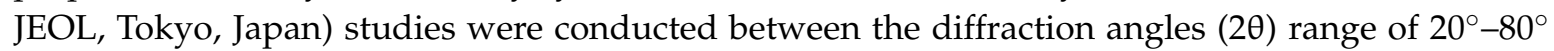
using $\mathrm{Cu}-\mathrm{K} \alpha$ source radiation with a wavelength of $1.54 \AA$ in order to explore the crystallinity, crystalline size, and microstructural phases. UV-visible spectrophotometer (Perkin Elmer-UV- -Vis. Lambda 950, PerkinElmer, MA, USA) analysis of the aqueous solution of $\mathrm{ZnO}$ nanoballs, sonicated for $15 \mathrm{~min}$ was carried out between the scan range of 300-600 $\mathrm{nm}$ to evaluate the band gap energy and optical properties. Fourier transform infrared spectroscopic (FTIR; Perkin Elmer-FTIR Spectrum-100, PerkinElmer, MA, USA) analysis was conducted in order to analyze the composition of the as-synthesized $\mathrm{ZnO}$ nanoballs. Raman-scattering spectroscopic (Perkin Elmer-Raman Station 400 series, PerkinElmer, MA, USA) technique was utilized for the examination of scattering properties of the $\mathrm{ZnO}$ nanoballs in the scan range of $200-550 \mathrm{~cm}^{-1}$. 


\section{Conclusions}

A simple, low cost, template-free hydrothermal method was adopted for the synthesis of $\mathrm{ZnO}$ nanoballs with highly rough surfaces. Morphological, structural, optical, crystal phases, vibrational and scattering properties of the $\mathrm{ZnO}$ nanoballs were evaluated through different analytic techniques such as FESEM, EDS, UV-Vis, FTIR and Raman scattering spectroscopy. ZnO nanoballs were further utilized for the fabrication of highly sensitive acetone electrochemical sensors through $I-V$ techniques. All the observations were recorded at room temperature and in the presence of the $0.1 \mathrm{M}$ PBS with $\mathrm{pH}$ of 7.4. High sensitivity of $\sim 472.33 \mu \mathrm{A} \cdot \mathrm{mM}^{-1} \cdot \mathrm{cm}^{-2}$ and LDR of $0.5 \mathrm{mM}-3.0 \mathrm{mM}$ were obtained. Hence, $\mathrm{ZnO}$ nanoballs based electrochemical sensors may introduce a relatively new avenue for the fabrication of efficient sensor for hazardous and carcinogenic chemicals and in environmental and healthcare monitoring.

Acknowledgments: This work has been supported in part by the National Natural Science Foundation of China (No. 51507144), China Postdoctoral Science Foundation funded project (Nos. 2015M580771 and 2016T90832); the Chongqing Science and Technology Commission (CSTC) (No. cstc2016jcyjA0400); Postdoctoral Science Funded Project of Chongqing (No. Xm2015016); Visiting Scholarship of State Key Laboratory of Power Transmission Equipment \& System Security and New Technology (No. 2007DA10512716423); and Fundamental Research Funds for the Central Universities (No. XDJK2015B005).

Author Contributions: Qu Zhou and Ahmad Umar conceived and designed the experiments; Qu Zhou, ChangXiang Hong, Ahmad Umar, and Ahmed Mohamed Ibrahim performed the experiments; ChangXiang Hong, Ahmad Umarand Yao Yao analyzed the data; Qu Zhou and Ahmad Umar wrote the paper; and Qu Zhou, Ahmed Mohamed Ibrahim, Rajesh Kumar, Sumaia Mohamed Talballa, S. H. Kim and Ahmad Umar reviewed and revised the manuscript. All authors read and approved the manuscript.

Conflicts of Interest: The authors declare no conflict of interest.

\section{References}

1. Kumar, R.; Al-Dossary, O.; Kumar, G.; Umar, A. Zinc oxide nanostructures for $\mathrm{NO}_{2}$ gas sensor applications: A review. Nano-Micro Lett. 2015, 7, 97-120. [CrossRef]

2. Schmidt-Mende, L.; MacManus-Driscoll, J.L. ZnO—Nanostructures, defects, and devices. Mater. Today 2007, 10, 40-48. [CrossRef]

3. Kumar, R.; Umar, A.; Kumar, G.; Nalwa, H.S. Antimicrobial properties of ZnO nanomaterials: A review. Ceram. Int. 2017, 43, 3940-3961. [CrossRef]

4. Kumar, R.; Umar, A.; Kumar, G.; Nalwa, H.S.; Kumar, A.; Akhtar, M.S. Zinc oxide nanostructure-based dye-sensitized solar cells. J. Mater. Sci. 2017, 52, 4743-4795. [CrossRef]

5. Chongsri, K.; Sinornate, W.; Boonyarattanakalin, K.; Pecharapa, W. Growth and characterization of Ga/F Co-doped ZnO nanorods/nanodisks via hydrothermal process. J. Nanosci. Nanotechnol. 2016, 16, 12962-12966. [CrossRef]

6. Park, G.C.; Lee, S.M.; Jeong, S.H.; Choi, J.H.; Lee, C.M.; Seo, T.Y.; Jung, S.-B.; Lim, J.H.; Joo, J. Enhanced photocatalytic activity of $\mathrm{ZnO}$ nanorods with tubular facet synthesized by hydrothermal method. J. Nanosci. Nanotechnol. 2016, 16, 11164-11168. [CrossRef]

7. Nouira, W.; Barhoumi, H.; Maaref, A.; Renault, N.J.; Siadat, M. Tailoring of analytical performances of urea biosensors using nanomaterials. J. Phys. Conf. Ser. 2013, 416, 12010. [CrossRef]

8. Zhang, F.; Yang, P.; Matras-Postolek, K. Au catalyst decorated silica spheres: Synthesis and high-performance in 4-nitrophenol reduction. J. Nanosci. Nanotechnol. 2016, 16, 5966-5974. [CrossRef] [PubMed]

9. Hieu, N.M.; Kim, H.; Kim, C.; Hong, S.-K.; Kim, D. A hydrogen sulfide gas sensor based on pd-decorated ZnO nanorods. J. Nanosci. Nanotechnol. 2016, 16, 10351-10355. [CrossRef]

10. Thirumalraj, B.; Rajkumar, C.; Chen, S.-M.; Lin, K.-Y. Determination of 4-nitrophenol in water by use of a screen-printed carbon electrode modified with chitosan-crafted $\mathrm{ZnO}$ nanoneedles. J. Colloid Interface Sci. 2017, 499, 83-92. [CrossRef] [PubMed]

11. Hu, Y.; Zhang, Z.; Zhang, H.; Luo, L.; Yao, S. Sensitive and selective imprinted electrochemical sensor for p-nitrophenol based on $\mathrm{ZnO}$ nanoparticles/carbon nanotubes doped chitosan film. Thin Solid Films 2012, 520, 5314-5321. [CrossRef] 
12. Dar, G.N.; Umar, A.; Zaidi, S.A.; Baskoutas, S.; Hwang, S.W.; Abaker, M.; Al-Hajry, A.; Al-Sayari, S.A. Ultra-high sensitive ammonia chemical sensor based on ZnO nanopencils. Talanta 2012, 89, 155-161. [CrossRef] [PubMed]

13. Chen, W.; Li, Q.; Xu, L.; Zeng, W. Gas sensing properties of $\mathrm{ZnO} / \mathrm{SnO}_{2}$ nanostructures. J. Nanosci. Nanotechnol. 2015, 15, 1245-1252. [CrossRef] [PubMed]

14. Mehta, S.K.; Singh, K.; Umar, A.; Chaudhary, G.R.; Singh, S. Ultra-high sensitive hydrazine chemical sensor based on low-temperature grown ZnO nanoparticles. Electrochim. Acta 2012, 69, 128-133. [CrossRef]

15. Hu, J.; Zhao, Z.; Sun, Y.; Wang, Y.; Li, P.; Zhang, W.; Lian, K. Controllable synthesis of branched hierarchical $\mathrm{ZnO}$ nanorod arrays for highly sensitive hydrazine detection. Appl. Surf. Sci. 2016, 364, 434-441. [CrossRef]

16. Ibrahim, A.A.; Umar, A.; Kumar, R.; Kim, S.H.; Bumajdad, A.; Baskoutas, S. $\mathrm{Sm}_{2} \mathrm{O}_{3}$-doped ZnO beech fern hierarchical structures for nitroaniline chemical sensor. Ceram. Int. 2016, 42, 16505-16511. [CrossRef]

17. Ahmad, N.; Umar, A.; Kumar, R.; Alam, M. Microwave-assisted synthesis of $\mathrm{ZnO}$ doped $\mathrm{CeO}_{2}$ nanoparticles as potential scaffold for highly sensitive nitroaniline chemical sensor. Ceram. Int. 2016, 42, 11562-11567. [CrossRef]

18. Ahmad, R.; Tripathy, N.; Ahn, M.-S.; Hahn, Y.-B. Highly stable hydrazine chemical sensor based on vertically-aligned $\mathrm{ZnO}$ nanorods grown on electrode. J. Colloid Interface Sci. 2017, 494, 153-158. [CrossRef] [PubMed]

19. Park, N.-K.; Lee, T.H.; Choi, H.Y.; Lee, T.J. Changing electric resistance of ZnO nano-rods by sulfur compounds for chemical gas sensor. J. Nanosci. Nanotechnol. 2015, 15, 1752-1755. [CrossRef] [PubMed]

20. Ameen, S.; Shaheer Akhtar, M.; Shin, H.S. Low temperature grown ZnO nanotubes as smart sensing electrode for the effective detection of ethanolamine chemical. Mater. Lett. 2013, 106, 254-258. [CrossRef]

21. Ibrahim, A.A.; Kumar, R.; Umar, A.; Kim, S.H.; Bumajdad, A.; Ansari, Z.A.; Baskoutas, S. Cauliflower-shaped $\mathrm{ZnO}$ nanomaterials for electrochemical sensing and photocatalytic applications. Electrochim. Acta 2016, 222, 463-472. [CrossRef]

22. Ameen, S.; Park, D.-R.; Akhtar, M.S.; Shin, H.S. Lotus-leaf like ZnO nanostructures based electrode for the fabrication of ethyl acetate chemical sensor. Mater. Lett. 2016, 164, 562-566. [CrossRef]

23. Jianjiao, Z.; Hongyan, Y.; Erjun, G.; Shaolin, Z.; Liping, W.; Chunyu, Z.; Xin, G.; Jing, C.; Hong, Z. Novel gas sensor based on $\mathrm{ZnO}$ nanorod circular arrays for $\mathrm{C}_{2} \mathrm{H}_{5} \mathrm{OH}$ gas detection. J. Nanosci. Nanotechnol. 2015, 15, 2468-2472. [CrossRef] [PubMed]

24. Gan, T.; Zhao, A.; Wang, S.; Lv, Z.; Sun, J. Hierarchical triple-shelled porous hollow zinc oxide spheres wrapped in graphene oxide as efficient sensor material for simultaneous electrochemical determination of synthetic antioxidants in vegetable oil. Sens. Actuators B Chem. 2016, 235, 707-716. [CrossRef]

25. Ya, Y.; Jiang, C.; Li, T.; Liao, J.; Fan, Y.; Wei, Y.; Yan, F.; Xie, L. A zinc oxide nanoflower-based electrochemical sensor for trace detection of sunset yellow. Sensors 2017, 17. [CrossRef] [PubMed]

26. Zhou, F.; Jing, W.; Wu, Q.; Gao, W.; Jiang, Z.; Shi, J.; Cui, Q. Effects of the surface morphologies of ZnO nanotube arrays on the performance of amperometric glucose sensors. Mater. Sci. Semicond. Process. 2016, 56, 137-144. [CrossRef]

27. Rodrigues, A.; Castegnaro, M.V.; Arguello, J.; Alves, M.C.M.; Morais, J. Development and surface characterization of a glucose biosensor based on a nanocolumnar ZnO film. Appl. Surf. Sci. 2017, 402, 136-141. [CrossRef]

28. Kitture, R.; Chordiya, K.; Gaware, S.; Ghosh, S.; More, P.A.; Kulkarni, P.; Chopade, B.A.; Kale, S.N. ZnO nanoparticles-red sandalwood conjugate: A promising anti-diabetic agent. J. Nanosci. Nanotechnol. 2015, 15, 4046-4051. [CrossRef] [PubMed]

29. Lei, Y.; Liu, X.; Yan, X.; Song, Y.; Kang, Z.; Luo, N.; Zhang, Y. Multicenter uric acid biosensor based on tetrapod-shaped ZnO nanostructures. J. Nanosci. Nanotechnol. 2012, 12, 513-518. [CrossRef] [PubMed]

30. Ahmad, R.; Tripathy, N.; Jang, N.K.; Khang, G.; Hahn, Y.B. Fabrication of highly sensitive uric acid biosensor based on directly grown ZnO nanosheets on electrode surface. Sens. Actuators B Chem. 2015, 206, 146-151. [CrossRef]

31. Ansari, S.G.; Wahab, R.; Ansari, Z.A.; Kim, Y.S.; Khang, G.; Al-Hajry, A.; Shin, H.S. Effect of nanostructure on the urea sensing properties of sol-gel synthesized ZnO. Sens. Actuators B Chem. 2009, 137, 566-573. [CrossRef]

32. Ali, S.M.U.; Ibupoto, Z.H.; Salman, S.; Nur, O.; Willander, M.; Danielsson, B. Selective determination of urea using urease immobilized on ZnO nanowires. Sens. Actuators B Chem. 2011, 160, 637-643. [CrossRef] 
33. Liu, H.; Gu, C.; Hou, C.; Yin, Z.; Fan, K.; Zhang, M. Plasma-assisted synthesis of carbon fibers/ZnO core-shell hybrids on carbon fiber templates for detection of ascorbic acid and uric acid. Sens. Actuators B Chem. 2016, 224, 857-862. [CrossRef]

34. Ghanbari, K.; Moloudi, M. Flower-like $\mathrm{ZnO}$ decorated polyaniline/reduced graphene oxide nanocomposites for simultaneous determination of dopamine and uric acid. Anal. Biochem. 2016, 512, 91-102. [CrossRef] [PubMed]

35. Copa, V.C.; Tuico, A.R.; Mendoza, J.P.; Ferrolino, J.P.R.; Vergara, C.J.T.; Salvador, A.A.; Estacio, E.S.; Somintac, A.S. Development of resistance-based pH sensor using zinc oxide nanorods. J. Nanosci. Nanotechnol. 2016, 16, 6102-6106. [CrossRef]

36. Ameen, S.; Akhtar, M.S.; Shin, H.S. Highly dense $\mathrm{ZnO}$ nanowhiskers for the low level detection of p-hydroquinone. Mater. Lett. 2015, 155, 82-86. [CrossRef]

37. Ameen, S.; Akhtar, M.S.; Shin, H.S. Highly sensitive hydrazine chemical sensor fabricated by modified electrode of vertically aligned zinc oxide nanorods. Talanta 2012, 100, 377-383. [CrossRef] [PubMed]

38. Umar, A.; Akhtar, M.S.; Al-Hajry, A.; Al-Assiri, M.S.; Dar, G.N.; Saif Islam, M. Enhanced photocatalytic degradation of harmful dye and phenyl hydrazine chemical sensing using $\mathrm{ZnO}$ nanourchins. Chem. Eng. J. 2015, 262, 588-596. [CrossRef]

39. Zheng, L.; Wan, Y.; Qi, P.; Sun, Y.; Zhang, D.; Yu, L. Lectin functionalized ZnO nanoarrays as a 3D nano-biointerface for bacterial detection. Talanta 2017, 167, 600-606. [CrossRef] [PubMed]

40. Kumar, R.; Kumar, G.; Umar, A. ZnO nano-mushrooms for photocatalytic degradation of methyl orange. Mater. Lett. 2013, 97, 100-103. [CrossRef]

41. Cullity, B.D. Elements of X-ray Diffraction, 2nd ed.; Addison-Wesley Publishing Co.: Reading, MA, USA, 1978.

42. Dogar, S.; Kim, S.M.; Kim, S.D. Ultraviolet photonic response of AlGaN/GaN high electron mobility transistor-based sensor with hydrothermal $\mathrm{ZnO}$ nanostructures. J. Nanosci. Nanotechnol. 2016, 16, 10175-10181. [CrossRef]

43. Patterson, A.L. The scherrer formula for X-ray particle size determination. Phys. Rev. 1939, 56, 978-982. [CrossRef]

44. Umar, A.; Alshahrani, A.A.; Algarni, H.; Kumar, R. CuO nanosheets as potential scaffolds for gas sensing applications. Sens. Actuators B Chem. 2017, 250, 24-31. [CrossRef]

45. Jeong, E.-S.; Kang, M.; Kim, H.-S. Surface acoustic wave propagation properties with ZnO thin film for thermo-electric sensor applications. J. Nanosci. Nanotechnol. 2016, 16, 10219-10224. [CrossRef]

46. Kim, S.; Park, S.; Kheel, H.; Lee, W.I.; Lee, C. Enhanced ethanol gas sensing performance of the networked Fe2O3-functionalized ZnO nanowire sensor. J. Nanosci. Nanotechnol. 2016, 16, 8585-8588. [CrossRef]

47. Umar, A.; Kumar, R.; Akhtar, M.S.; Kumar, G.; Kim, S.H. Growth and properties of well-crystalline cerium oxide $\left(\mathrm{CeO}_{2}\right)$ nanoflakes for environmental and sensor applications. J. Colloid Interface Sci. 2015, 454, 61-68. [CrossRef] [PubMed]

48. Silambarasan, M.; Saravanan, S.; Soga, T. Effect of Fe-doping on the structural, morphological and optical properties of $\mathrm{ZnO}$ nanoparticles synthesized by solution combustion process. Physica E 2015, 71, 109-116. [CrossRef]

49. Dong, Y.; Feng, C.; Jiang, P.; Wang, G.; Li, K.; Miao, H. Simple one-pot synthesis of ZnO/Ag heterostructures and the application in visible-light-responsive photocatalysis. RSC Adv. 2014, 4, 7340-7346. [CrossRef]

50. Rahman, M.M.; Khan, S.B.; Asiri, A.M.; Alamry, K.A.; Khan, A.A.P.; Khan, A.; Rub, M.A.; Azum, N. Acetone sensor based on solvothermally prepared ZnO doped with Co3O4 nanorods. Microchim. Acta 2013, 180, 675-685. [CrossRef] [PubMed]

51. Khan, S.B.; Faisal, M.; Rahman, M.M.; Jamal, A. Low-temperature growth of ZnO nanoparticles: Photocatalyst and acetone sensor. Talanta 2011, 85, 943-949. [CrossRef] [PubMed]

52. Ibrahim, A.A.; Hwang, S.W.; Dar, G.N.; Kim, S.H.; Abaker, M.; Ansari, S.G. Synthesis and characterization of Gd-doped ZnO nanopencils for acetone sensing application. Sci. Adv. Mater. 2015, 7, 1241-1246. [CrossRef]

53. Rahman, M.M.; Alam, M.M.; Asiri, A.M.; Islam, M.A. Fabrication of selective chemical sensor with ternary $\mathrm{ZnO} / \mathrm{SnO}_{2} / \mathrm{Yb}_{2} \mathrm{O}_{3}$ nanoparticles. Talanta 2017, 170, 215-223. [CrossRef] [PubMed]

54. Wang, C.-C.; Weng, Y.-C.; Chou, T.-C. Acetone sensor using lead foil as working electrode. Sens. Actuators B Chem. 2007, 122, 591-595. [CrossRef]

55. Chou, T.-C. An amperometric acetone sensor by using an electro-deposited Pb-modified electrode. Z. Naturforsch. B 2006, 61, 560-564. 
56. Rahman, M.M.; Khan, S.B.; Jamal, A.; Faisal, M.; Asiri, A.M. Fabrication of highly sensitive acetone sensor based on sonochemically prepared as-grown $\mathrm{Ag}_{2} \mathrm{O}$ nanostructures. Chem. Eng. J. 2012, 192, 122-128. [CrossRef]

57. Saravanan, T.; Raj, S.G.; Chandar, N.R.K.; Jayavel, R. Synthesis, optical and electrochemical properties of $\mathrm{Y}_{2} \mathrm{O}_{3}$ nanoparticles prepared by co-precipitation method. J. Nanosci. Nanotechnol. 2015, 15, 4353-4357. [CrossRef] [PubMed]

58. Alharbi, N.D.; Shahnawaze Ansari, M.; Salah, N.; Khayyat, S.A.; Khan, Z.H. Zinc oxide-multi walled carbon nanotubes nanocomposites for carbon monoxide gas sensor application. J. Nanosci. Nanotechnol. 2016, 16, 439-447. [CrossRef] [PubMed]

59. Ahmad, R.; Tripathy, N.; Jung, D.-U.-J.; Hahn, Y.-B. Highly sensitive hydrazine chemical sensor based on $\mathrm{ZnO}$ nanorods field-effect transistor. Chem. Commun. 2014, 50, 1890-1893. [CrossRef] [PubMed]

60. Fan, Z.; Wang, D.; Chang, P.-C.; Tseng, W.-Y.; Lu, J.G. ZnO nanowire field-effect transistor and oxygen sensing property. Appl. Phys. Lett. 2004, 85, 5923-5925. [CrossRef]

61. Gujarati, T.P.; Ashish, A.G.; Rai, M.; Shaijumon, M.M. Highly ordered vertical arrays of $\mathrm{TiO}_{2} / \mathrm{ZnO}$ hybrid nanowires: Synthesis and electrochemical characterization. J. Nanosci. Nanotechnol. 2015, 15, 5833-5839. [CrossRef] [PubMed]

62. Majumder, S. Synthesis and characterisation of $\mathrm{SnO}_{2}$ films obtained by a wet chemical process. Mater. Sci. 2009, 27, 123-129.

63. Ahmad, R.; Tripathy, N.; Ahn, M.-S.; Hahn, Y.-B. Development of highly-stable binder-free chemical sensor electrodes for p-nitroaniline detection. J. Colloid Interface Sci. 2017, 494, 300-306. [CrossRef] [PubMed]

64. Behera, B.; Chandra, S. Catalyst-free synthesis of $\mathrm{ZnO}$ nanowires on oxidized silicon substrate for gas sensing applications. J. Nanosci. Nanotechnol. 2015, 15, 4534-4542. [CrossRef] [PubMed]

(C) 2017 by the authors. Licensee MDPI, Basel, Switzerland. This article is an open access article distributed under the terms and conditions of the Creative Commons Attribution (CC BY) license (http:/ / creativecommons.org/licenses/by/4.0/). 